\title{
Г.B. Kpycip
}

Одеська національна академія харчових технологій, вул. Канатна, 112, Одеса, 65039

\section{ЕКОЛОГІЧНІ АСПЕКТИ ВИНОРОБНОГО ПІДПРИЄМСТВА}

Розглянуто питання аналізу твердих відходів виноробних підприємств в якості екологічних аспектів виноробних підприємств, а також зниження навантаження на навколишнє середовище за рахунок використання твердих відходів виноробства як вторинної сировини для отримання нового продукту. Наведено результати аналізу твердих відходів виноробних підприємств як иінної сировини для одержання кормової добавки. Доведено, щчо переважаючою речовиною хімічного складу вичавки і гребенів є вуглеводи, а саме иелюлоза.

Ключові слова: Виноробство - Відходи - Екологія.

\section{ЭКОЛОГИЧЕСКИЕ АСПЕКТЫ ВИНОДЕЛЬЧЕСКОГО ПРЕДПРИЯТИЯ}

Рассмотрены вопросы анализа твердых отходов винодельческих предприятий в качестве экологических аспектов винодельческих предприятий, а также снижения нагрузки на окружающую среду за счет использования твердых отходов виноделия как вторичного сырья для получения нового продукта. Приведены результаты анализа твердых отходов винодельческих предприятий как иенного сырья для получения кормовой добавки. Доказано, что превосходящим веществом выжимки и гребней являются углеводы, а именно иеллюло$3 a$.

Ключевые слова: Виноделие - Отходы - Экология.

\section{THE WINERY ECOLOGICAL ASPECTS}

The issues of wineries solid waste analysis as the environmental aspects of the wineries, as well as reducing the burden on the environment through the use of wineries solid wastes as secondary raw material for the new product obtaining are considered. The results of the wineries solid waste analysis as a valuable raw material for feed additive obtaining are given. It is proved that the dominant substance of marc and crests chemical composition are carbohydrates, namely cellulose.

Keywords: Wine Making - Waste - Environment.

\section{I. ВСТУП}

Відомо, що виноград за вмістом корисних компонентів $\epsilon$ найбагатшим представником багаторічних культурних рослин. Вагома частина складових винограду після його промислової переробки залишається у вторинних продуктах відходах виноробства, основними видами яких є: вичавка, гребені, дріжджові і гущові осади, коньячна барда. Кількість вторинних продуктів (відходів) складають від 10 до 20\% всієї кількості винограду, що переробляється.

Бурхливий розвиток високих промислових технологій, комп'ютеризації науки і виробництва дозволив останнім часом удосконалити способи переробки відходів виноробства і виробництво нової продукції з відходів виноробства. Однак, незважаючи на це, до цього часу залишається гострою проблема утилізації вторинних сировинних ресурсів.

Основними відходами виноробної промисловості є гребені, що відокремлюються від грон ви- нограду перед його пресуванням; вичавка, яку одержано після пресування винограду при виготовленні білих і рожевих вин; дріжджові осади, які осідають на дно бочок і резервуарів після бродіння, і осади, що виділяються після спиртування сусла і вина; винний камінь, який відкладається на стінках бочок при бродінні сусла і витримці вина. 3 них можна і потрібно, як у всіх розвинених виноробних країнах, виробляти затребувані ринком товари [1].

Одним з рішень проблеми утилізації відходів виноробства $\epsilon$ переробка вичавки і гребенів в кормову добавку. Для успішного вирішення цієї задачі необхідно володіти детальною інформацією щодо хімічного складу відходів виноробства, які плануються до подальшої переробки.

\section{II. ОСНОВНА ЧАСТИНА}

Гроно винограду складається 3 м'якоті - джерела соку і займає 75-80\% всієї кількості ягоди. Решта - суха частина, яка отримана після віджи- 
мання соку (сусла), відноситься до твердої фази вичавки. Вона об'єднує гребені, фрагменти шкірки, насіння і частинки пульпи діаметром до 3 мм. Вологість свіжовіджатої вичавки становить 48-55\%, щільність-в межах 1,0-1,2 г /см ${ }^{3}$, вологоємність30-60 мл/100 г.

Вагове співвідношення складових частин у вичавці варіює в значному діапазоні і залежить від сорту винограду, з якого отримана вичавка, від метеорологічних умов року і від того, як і на яких пресах проводилося пресування, в середньому вагове співвідношення шкірки, гребенів та насіння складає 2:1:1 [2].

3100 кг вичавки можна виділити відповідно 15-24 кг сухої шкірки, 21-26 кг насіння, а також потенційний спирт у кількості 2-7 л і виннокислі сполуки - від 0,4 до 3,0 кг. Склад вичавки аналогічний складу винограду. У ній присутні ліпіди, азотисті сполуки, вода, вуглеводи, виннокислі сполуки, фенольні речовини, вітаміни, органічні кислоти. Тому одним 3 найважливих етапів досліджень було визначення хімічного складу виноградної вичавки та гребенів [3]. Результати визначення хімічного складу вичавки, одержаної після пресування, наведено у таблиці 1.

Таблиця 1 - Хімічний склад вичавки

\begin{tabular}{|l|l|}
\hline \multicolumn{1}{|c|}{ Група речовин } & \% в перерах. на СР \\
\hline Ліпіди & $5,5-9,0$ \\
\hline Вуглеводи (в тому числі): & $6,0-16,1$ \\
\hline $\begin{array}{c}\text {-моносахариди (глюкоза, } \\
\text { маноза) }\end{array}$ & $11,0-19,0$ \\
\hline -целюлоза & $16,1-27,2$ \\
\hline -пектин & $5,0-8,0$ \\
\hline Білок (загальний) & $14,0-15,0$ \\
\hline Зола & $1,0-1,5$ \\
\hline Фенольні сполуки (загальні) & $3,0-6,0$ \\
\hline
\end{tabular}

Як свідчать результати експериментальних досліджень, переважаючою речовиною хімічного складу вичавки є вуглеводи: целюлоза (16-27\%) та пектинові речовини (5-8\%). Відомо, що при гідролізі пектинових речовин утворюються уронові кислоти, які мають велике значення при знезараженні таких шкідливих речовин, як феноли [4].

Дані, які наведені в таблиці 1, показали, що виноградна вичавка $\epsilon$ цінною сировиною для отримання кормової добавки для крупної рогатої худоби за вмістом у ній ліпідів, білків, вуглеводів, азотистих та інших сполук.

Серед поживних речовин вичавки велике значення має білок, який складає 14,0-15,0\%. Біологічна цінність білку залежить від його амінокислотного складу [3]. Тому наступним етапом дослідження було вивчення амінокислотного складу вичавки. У таблиці 2 наведено вміст деяких амінокислот в виноградній вичавці.

В процесі досліджень амінокислотного складу встановлено, що виноградна вичавка багата такими критичними амінокислотами, як триптофан $(7,2 \%)$ і лізин (7,5\%), наявність яких сприяють на- рощуванню маси і нормальній роботі обміну речовин тварин [5].

Таблиця 2 - Вміст деяких амінокислот у виноградній вичавці

\begin{tabular}{|l|l|}
\hline Амінокислоти & \% в перерах. на СР \\
\hline Лізин & 7,5 \\
\hline Метіонін & 1,0 \\
\hline Цистин & 0,7 \\
\hline Триптофан & 7,2 \\
\hline Аргінін & 5,1 \\
\hline Валін & 7,2 \\
\hline Гістидин & 3,5 \\
\hline Лейцин & 6,2 \\
\hline Ізолейцин & 5,6 \\
\hline Треонін & 4,8 \\
\hline Фенілаланін & 2,9 \\
\hline
\end{tabular}

Як було зазначено вище, вичавка містить фрагменти шкірки і насіння у співвідношенні 2:1.

Тому одним 3 найважливіших етапів досліджень було більш детальне вивчення хімічного складу як насіння так і шкірочки, які входять до складу вичавки. Результати визначення хімічного складу насіння наведено у таблиці 3.

Таблиця 3 - Хімічний склад насіння

\begin{tabular}{|l|l|}
\hline Група речовин & \% в перерах. на СР \\
\hline Ліпіди & $15,9-16,8$ \\
\hline $\begin{array}{l}\text { Вуглеводи (в тому чис- } \\
\text { лі): }\end{array}$ & $41,1-43,7$ \\
\hline $\begin{array}{c}\text {-моносахариди } \\
\text { (глюкоза, маноза) }\end{array}$ & $0,9-1,1$ \\
\hline \multicolumn{1}{|c|}{-целюлоза } & $24,3-25,5$ \\
\hline Білок (загальний) & $16,0-17,2$ \\
\hline Зола & $2,6-3,0$ \\
\hline
\end{tabular}

Вміст ліпідів у насінні значний (15,9-16,8\%), тому важливо вивчення його жирно кислотного складу. 3 результатів досліджень наведених в таблиці 3 можна зробити висновок, що насіння винограду характеризується значним вмістом ліпідів (15,9-16,8\%). Жирнокислотний склад ліпідної частини насіння, що входить до складу вичавки, наведено в таблиці 4.

Таблиця 4 - Жирнокислотний склад насіння

\begin{tabular}{|l|l|}
\hline Жирна кислота & Вміст мг/100 г \\
\hline Олеїнова кислота & 3,4 \\
\hline Пальмітинова кислота & 19,9 \\
\hline Стеаринова кислота & 21,6 \\
\hline Лінолева кислота & 1,3 \\
\hline Ліноленова кислота & 1,1 \\
\hline Арахідонова кислота & 19,0 \\
\hline
\end{tabular}

У ліпідах, виділених з насіння винограду, міститься 87,0-93,0\% фізіологічно цінних ненасичених жирних кислот, в тому числі лінолевої $(1,3 \%)$, ліноленової $(1,1 \%)$ олеїнової $(3,4 \%)$, арахідонової кислот (19,0\%), які є основним джерелом запасного енергетичного матеріалу, виконують надзви- 
чайно важливі фізіологічні функції в метаболізмі клітин, у ферментативних процесах [5].

Шкірочка складає в середньому 9-11\% ваги виноградного грона. У ній знаходяться дубильні, барвні і частково ароматичні речовини, які відповідальні за колір, терпкість і аромат, що притаманний сорту винограду. Основна маса шкірочки складає від 60 до 80 \% води, інша частина відведена вуглеводам, ліпідам, білкам та ін. [6]. Результати вивчення хімічного складу шкірочки наведено у таблиці 5.

Таблиця 5 - Хімічний склад шкірочки

\begin{tabular}{|l|l|}
\hline Група речовин & \% в перерах. на СP \\
\hline Ліпіди & $0,3-0,4$ \\
\hline $\begin{array}{l}\text { Вуглеводи (в тому чи- } \\
\text { слі): }\end{array}$ & $29,0-30,0$ \\
\hline $\begin{array}{c}\text {-моносахариди } \\
\text { (глюкоза, маноза) }\end{array}$ & $61,0-62,0$ \\
\hline \multicolumn{1}{|c}{-целюлоза } & $28,0-39,0$ \\
\hline Білок (загальний) & $5,1-5,8$ \\
\hline Зола & $1,0-1,7$ \\
\hline
\end{tabular}

Як свідчать результати експериментальних досліджень, шкірочка багата вуглеводами, які представлені геміцелюлозами $(61,0-62,0 \%)$ та целюлозою $(28,0-39,0 \%)$, але бідна ліпідами $(0,3-$ $0,4 \%)$ та білком $(5,1-5,8 \%)$.

Гребені у винограді складають 3,8-8,5\% маси грона (в середньому 5,5\%) [7]. Відокремлені від ягід вологі гребені містять деяку кількість сусла, що змочує їх поверхню. Сусло можна відокремити пресуванням або промиванням гребенів водою. Його вихід становить 1 дал 31 тонни переробленого винограду. Результати визначення хімічного складу гребенів, одержаних після пресування, наведено у таблиці 6.

Таблиця 6 - Хімічний склад гребенів

\begin{tabular}{|l|l|}
\hline Група речовин & \% в перерах. на СР \\
\hline Ліпіди & $0,1-0,3$ \\
\hline $\begin{array}{l}\text { Вуглеводи (в тому чис- } \\
\text { лі): }\end{array}$ & $4,6-5,8$ \\
\hline \multicolumn{1}{|c}{ целюлоза } & $18-31$ \\
\hline \multicolumn{1}{|c}{ пектин } & $3,1-4,8$ \\
\hline Білок (загальний) & $2,1-2,4$ \\
\hline Зола & $1-1,4$ \\
\hline $\begin{array}{l}\text { Фенольні сполуки (за- } \\
\text { гальні) }\end{array}$ & $1-5,4$ \\
\hline
\end{tabular}

Як видно з даних, наведених у табл. 6, гребені, як і вичавка, є цінною сировиною для виробни- цтва кормової добавки. Переважаючою речовиною хімічного складу гребенів $є$ вуглеводи, що містять переважно целюлозу (18-31\%), та пектинові речовини $(3,1-4,8 \%)$.

\section{IV. ВИСНОВОК}

Таким чином, аналіз твердих відходів виноробства (гребенів і вичавки) показав, що переважаючою речовиною хімічного складу вичавки (шкірочки та насіння) та гребенів є вуглеводи, а саме целюлоза. Дані види відходів $\epsilon$ цінною сировиною для отри мання кормової добавки, тому що містять значну кількість поживних речовин, які в свою чергу збагачують раціон харчування тварин.

\section{ЛІТЕРАТУРА}

1. Крусир Г.В., Кирияк А.В., Соколова И.Ф. Экологические аспекты винодельческих предприятий // Екологічна безпека №2/2011(12).- Кременчуг.-2011.- С. 128-132

2. БрыкаловА. В., Белик Е. В., Антонова Н. А. Разработка технологии получения масла из косточек винограда // Сборник научных трудов «Современные достижения в химии и биотехнологии». Ставрополь.-2005.- С. $64-65$.

3. Ермаков А.И., Арасимович В.В., Ярош Н.П., Перуанский Г.А., Луковникова Г.А., Иконникова М.И. Методы биохимического исследования растений // 3-е изд. Ленинград.- 1987.- С. 430.

4. Бареева Н.Н., Донченко Л.В. Виноградные выжимки - перспективный промышленный источник пектиновых веществ // Кубанский государственный аграрный университет №20(04).- Краснодар.- 2006.- С. 36-42.

5. Левицкий А.П., Чайка И.К., Ходаков И.В., Охрименко А.Н., Пужанская И.П., Дерменко П.П. Кормовая ценность зерно-виноградных экструдатов // Зернові продукті і комбікорми №1.Одесса.- 2011.- С. $32-34$.

6. Коробко В.И. Виноградные выжимки - важный резерв кормов // Научный журнал «Наука, техника, технология».- Одесса- 2002.- С. 64 - 66.

7. Карунский А.И., Дашковская О.П., Иванов А.П. Эффективность использования виноградных выжимок при производстве комбикормов // Наукові праці, випуск 24.- Одесса.- 2003.- С.193-196.

Получена в редакции 15.05.2013, принята к печати 04.06.2013 